\title{
Substrate but not seed size affects seed germination of Dypsis onilahensis (Jum. \& H. Perrier) Beentje \& J. Dransf
}

\section{Germinação de Dypsis onilahensis (Jum. \& H. Perrier) Beentje \& J. Dransf. em função do tamanho da semente e substratos}

\author{
Petterson Baptista da Luz $^{1 *}$; Thalita Neves Marostega²; Bruno Nicchio ${ }^{3}$; \\ Leonarda Grillo Neves ${ }^{1}$
}

\begin{abstract}
Dypsis onilahensis, commonly known as sibara palm, is a palm tree with enormous ornamental potential. Commercial propagation occurs through seeds, but few studies have evaluated the factors that affect the germination process of this species. Thus, we aimed at evaluating the effects of seed size and substrate on D. onilahensis germination. We used a completely randomized experimental design and a $2 \times 3$ factorial scheme with two seed sizes $(>15 \mathrm{~mm}$ and $<15 \mathrm{~mm}$ in diameter) and three substrate types (sand, Plantmax ${ }^{\circledR}$, and vermiculite), with four replications of 15 seeds. We analyzed germination percentage ( $\mathrm{G} \%$ ), number of germinated seeds (NGS), and germination speed index (GSI). Data underwent variance analysis, and means were compared by the Tukey test at $5 \%$ probability. Germination began 73 days after sowing. Seed size had no effect on germination. Among substrates, vermiculite showed the best results for GSI, NGS, and G\%, followed by sand and then by Plantmax ${ }^{\circledR}$. Our study provides the first data on factors that affect the germination of this palm tree species.
\end{abstract}

Key words: Palm tree, ornamental, seedling emergence

\section{Resumo}

A espécie Dypsis onilahens, popularmente conhecida como Sibara, é uma palmeira ainda rara em cultivo no país, porém com grande potencial ornamental pela graciosidade de suas folhas. A propagação comercial é sexuada e há poucos os estudos sobre a germinação de sementes dessa espécie, que pode ser influenciada por vários fatores. Desta forma, o objetivo deste trabalho foi estudar o efeito do tamanho da semente e o uso de diferentes tipos de substratos na germinação de D. onilahens. O delineamento experimental foi o inteiramente casualizado em esquema fatorial 2 × 3 ( 2 tamanhos de sementes: $>15 \mathrm{~mm}$ e $<15 \mathrm{~mm}$ de diâmetro; e 3 tipos de substratos: areia, Plantmax ${ }^{\circledR}$ e vermiculita), com quatro repetições de 15 sementes. Os dados foram submetidos à análise de variância e as médias comparadas pelo teste de Tukey, a $5 \%$ de probabilidade. Determinou-se a porcentagem de germinação $(\mathrm{G} \%)$, o número de sementes germinadas (NSG) e o Índice de Velocidade de Germinação (IVG). A germinação teve início aos 73 dias após a instalação do experimento. Os resultados demonstraram que não houve efeito significativo para tamanho de sementes, contudo para o substrato, verifica-se que a vermiculita foi

\footnotetext{
${ }^{1}$ Prof $^{\text {as }}$ Dras, Programa de Pós-Graduação em Genética e Melhoramento de Plantas, Universidade do Estado de Mato Grosso, UNEMAT, Campus Universitário de Cáceres, Cáceres, MT, Brasil. E-mail: petterbaptista@yahoo.com.br; leonardaneves@ unemat.br

2 Discente do Curso de Mestrado em Genética e Melhoramento de Plantas, UNEMAT, Campus Universitário de Cáceres, Cáceres, MT, Brasil. E-mail: tamarostega@gmail.com

${ }^{3}$ Discente do Curso de Graduação em Agronomia, UNEMAT, Campus Universitário de Cáceres, Cáceres, MT, Brasil. E-mail: bruno_nicchio@hotmail.com

* Author for correspondence
} 
o que apresentou os melhores resultados para IVG, NSG e G (\%), seguido do substrato areia e do substrato comercial Plantmax. Assim sendo, o presente estudo fornece as primeiras informações sobre a germinação dessa palmeira.

Palavras-chave: Palmeira, ornamental, emergência de plântula

Commonly known as sibara palm, the palm tree Dypsis onilahensis (Jum. \& H. Perrier) Beentje \& J. Dransf. is indigenous to Madagascar. Its attractive ornamental features include its graceful leaves. This palm tree is grown in full sunlight in parks and gardens, either as a single tree or in groups or rows. D. onilahensis reproduces through seeds that germinate within 90 days of falling to the ground, and each plant produces approximately 1100 fruit during the summer season (LORENZI et al., 2004).

Palm trees, with few exceptions, are propagated with seeds that germinate slowly and unevenly. Producers employ seed propagation primarily with palms that do not produce tillers, such as Euterpe edulis (Jussara) and Euterpe precatória (Açaí) (AGUIAR; MENDONÇA, 2003). Many factors, including maturation stage, pericarp presence or absence, time between harvest and sowing, seed dormancy, temperature, and substrate, affect the germination process of palms (MEEROW, 1991). Regarding germination substrate, important variables include non-toxicity to seeds, absence of microorganisms, and an appropriate ratio between moisture and aeration (COPELAND; McDONALD, 1995). Furthermore, the substrate must be evenly moist to meet seed water demands for germination and growth (FIGLIOLIA et al., 1993). Among substrates, vermiculite has been recommended for seed germination (PIVETTA et al., 2008; REGO et al., 2009).

Depending on palm species, producers must also take plant traits into account, including seed size, water and light requirements, and ease in counting and evaluating seedlings after germination (BRASIL, 2009). The effects of seed size on plant physiology and overall quality have been studied for several ornamental species, but less often for forest species. Seed partitioning by size has been used to promote seed physiological quality and to find ideal seed size ranges for the propagation of plant species (TORRES, 1994).

Because few reports have focused on germination of $\mathrm{D}$. onilahensis, we aimed to evaluate the effects of seed size and substrate type on the germination of this species. Beginning in January 2012, D. onilahensis fruit were harvested from stock plants in Limeira, SP, Brazil. Harvested fruit were wrapped in newspaper and placed inside plastic bags for 10 days, after which they were taken to the LST. During processing, the pericarp and mesocarp were removed by hand rubbing of diaspores (endocarp and seed) against a sieve, after which seeds were washed in tap water and shadedried during the daytime. A completely randomized experimental design was used with a 2 x 3 factorial scheme that included two seed sizes $(>15 \mathrm{~mm}$ and $<15 \mathrm{~mm}$ in diameter) and three substrates (sand, Plantmax ${ }^{\circledR}$, and vermiculite), with four replications of 15 seeds. Seeds were germinated in 'Gerbox' plastic trays filled with substrate. Moisture was maintained by daily watering with distilled water. Air temperature was monitored daily and reached a high of $29^{\circ} \mathrm{C}$ and a low of $24^{\circ} \mathrm{C}$. The number of germinated seeds (i. e., those with a protruding bud) was counted daily. The period during which substantial germination was occurring lasted for approximately 240 days after sowing. Germination percentage $(\mathrm{G} \%)$, number of germinated seeds (NGS), and germination speed index (GSI) were determined using the formulas proposed by Maguire (1962). Data underwent variance analysis with the SISVAR® software (FERREIRA, 2000), and means were compared by the Tukey test at 5\% probability, using NGS data transformed to $\sqrt{x}+1$ and $\mathrm{G} \%$ transformed to $\arcsin \sqrt{ }(\mathrm{x} / 100)$. 
Germination began 73 days after sowing. This interval is longer than that previously reported for Dypsis decaryi, whose germination peaked six days after sowing (LUZ et al., 2008), Table 1 shows the mean values of $\mathrm{G} \%$, NGS, and GSI of D. onilahensis seeds on three substrates. There was no significant effect of seed size, suggesting that this factor does not affect the germination of $\mathrm{D}$. onilahensis. Nevertheless, Andrade and Paulino (1995) observed that despite having no effects on germination, the seed size of the juçara palm (Euterpe edulis) affected seedling vigor, and plants from larger seeds had greater root and shoot development. Thus, the same authors recommended the use of larger seeds in palm plantations. Similar results have been reported by other authors for the carnauba (Copernicia hospita) and juçara (E. edulis) palms (OLIVEIRA et al., 2009; FOLÉIS et al., 2012).

Table 1. Germination speed index (GSI), number of germinated seeds (NGS), and germination percentage (G\%) of Dypsis onilahensis Jum. seeds on three types of substrates. UNEMAT, Cáceres, MT, Brazil, 2012.

\begin{tabular}{cccc}
\hline \multirow{2}{*}{ Substrate } & \multicolumn{3}{c}{ Vigor Test } \\
\cline { 2 - 4 } & GSI & NGS & G (\%) \\
\hline Plantmax $^{\circledR}$ & $(0.025)^{1} 0.002 \mathrm{c}$ & $(1.19)^{1} 0.50 \mathrm{c}$ & $(6.41)^{1} 3.33 \mathrm{c}$ \\
Sand & $(0.134) 0.020 \mathrm{~b}$ & $(1.84) 2.62 \mathrm{~b}$ & $(23.38) 17.49 \mathrm{~b}$ \\
Vermiculite & $(0.209) 0.048 \mathrm{a}$ & $(2.54) 6.00 \mathrm{a}$ & $(38.27) 39.99 \mathrm{a}$ \\
\hline V. C. $(\%)$ & 41.14 & 26.78 & 72.81 \\
\hline
\end{tabular}

Means within columns followed by the same letter do not differ by the Tukey test at 5\% probability.

${ }^{1}$ Transformed data.

Among substrates, vermiculite yielded the highest values for all analyzed variables, followed by sand and then by the commercially available Plantmax ${ }^{\circledR}$. Similarly, Andrade et al. (1999) observed that vermiculite provided the highest percentage of normal seedlings and emergence speed index in E. edulis when compared to soil and sand. Vermiculite also improved the germination of Archontophoenix cunninghamii H. Wendl. \& Drude seeds in comparison with sphagnum moss and sand (PIVETTA et al., 2008). Finally, Lima Junior (2010) identified vermiculite as being the best germination substrate for forest species, especially for roundshaped medium and large seeds with high moisture demand. Nevertheless, some studies have reported contrasting results. For example, Ledo et al. (2002) observed that sand yielded higher germination percentages and GSI for seeds of peach palm (Bactris gasipaes) compared with vermiculite. Luz et al. (2008) found no significant differences in D. decaryi germination using sand and vermiculite. In Brazil, the standardized germination test for E. edulis requires the use of sand as the substrate (BRASIL, 2009).

Germination of D. onilahensis was slow and uneven, as has been previously reported (MEEROW, 1991). Germination began on day 73 of the experiment and began to slow at approximately 147 days. Steady germination ended by day 223, but occasional germinating seeds were observed for another 60 days. Figure 1 shows the cumulative percentage of $\mathrm{D}$. onilahensis germination on the three studied substrates.

In summary, the present work shows that vermiculite provided the highest GSI, NGS, and $\mathrm{G} \%$ for D. onilahensis seeds, while seed size had no influence on germination. 
Figure 1. Cumulative germination (\%) at different germination times (days) on Plantmax ${ }^{\circledR}$, sand, and vermiculite substrates. UNEMAT, Cáceres, MT, Brazil, 2012.

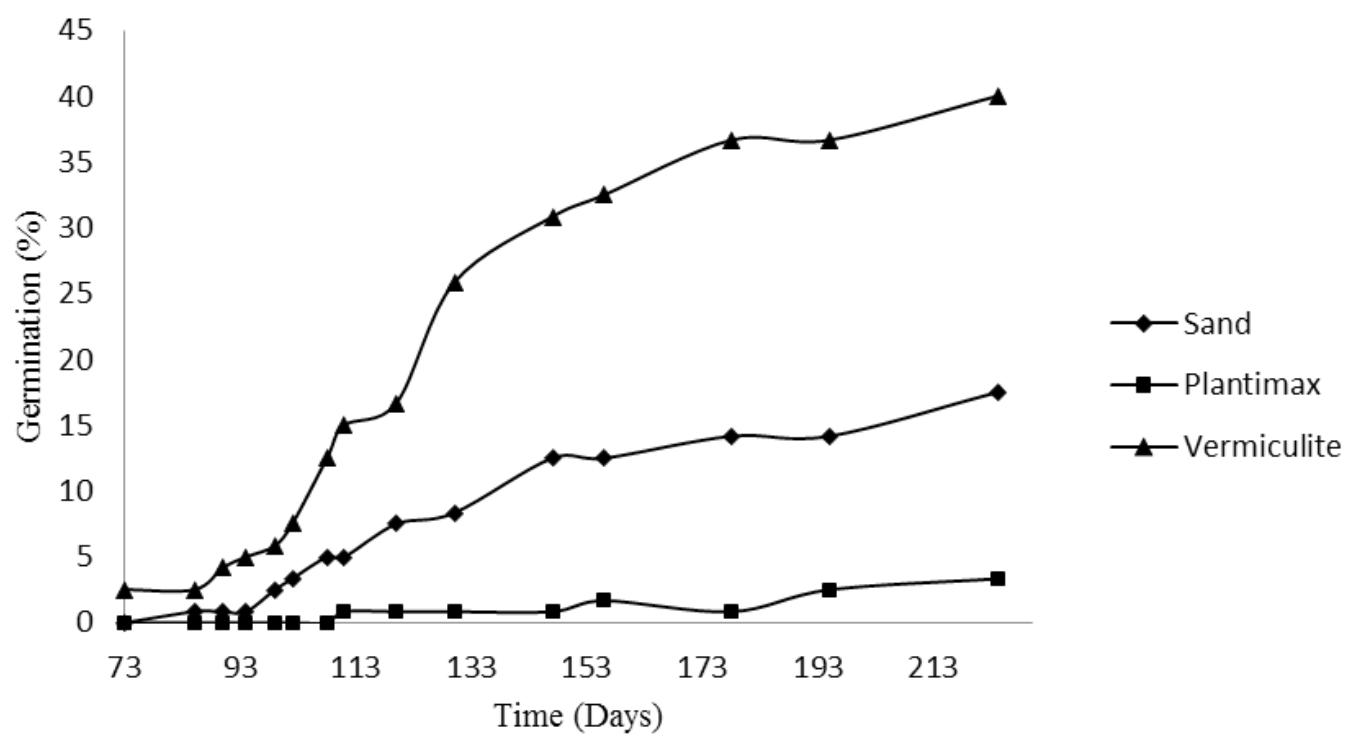

\section{Referências}

AGUIAR, M. O.; MENDONÇA, M. S. Morfoanatomia da semente de Euterpe precatoria Mart. (Palmae). Revista Brasileira de Sementes, Londrina, v. 25, n. 1, p. 37-42, 2003.

ANDRADE, A. C. S.; PAULILO, M. T. S. Efeito da massa da semente na velocidade de germinação e no desenvolvimento de plântulas de Euterpe edulis Mart. (palmiteiro). Informativo Abrates, Londrina, v. 5, n. 2, p. 189, 1995.

ANDRADE, C. S. A.; LOUREIRO, M. B.; SOUZA, A. D. O.; RAMOS, F. N.; CRYZ, A. P. M. Reavaliação do efeito do substrato e da temperatura na germinação de sementes de palmiteiro (Euterpe edulis Mart.). Revista Árvore, Viçosa, MG, v. 23, n. 3, p. 279-283, 1999.

BRASIL. Ministério da Agricultura, Pecuária e Abastecimento. Regras para análise de sementes. Brasília: Mapa/ACS, 2009. 395 p.

COPELAND, L. O.; McDONALD, M. B. Principle of seed science and technology. New York: Chapmen \& Hall, 1995. 409 p.

FERREIRA, D. F. Análises estatísticas por meio do Sisvar para Windows versão 4. 0. In: REUNIÃO ANUAL DA REGIÃO BRASILEIRA DA SOCIEDADE INTERNACIONAL DE BIOMETRIA, 45., 2000, São Carlos. Anais... São Carlos: UFSCar, 2000. p. 255-258.

FIGLIOLIA, M. B.; OLIVEIRA, E. C.; PIÑARODRIGUES, F. C. M. Análise de sementes. In:
AGUIAR, I. B.; PIÑA RODRIGUES, F. C. M.; FIGLIOLIA, M. B. (Coord.). Sementes florestais tropicais. Brasília: ABRATES, 1993. p. 137-174.

FOLÉIS, G. R. S.; LUZ, P. B.; PAIVA SOBRINHO, S.; NEVES, L. G. Tamanho do diásporo e substratos na germinação de sementes de palmeira Jussara (Euterpe edulis Mart.). Magistra, Cruz das Almas, v. 24, n. 2, p. 103-107, 2012.

LEDO, A. da S.; MEDEIROS-FILHO, S.; LEDO, F. J. da S.; ARAÚJO, E. C. Efeito do tamanho da semente, do substrato e pré-tratamento na germinação de sementes de pupunha. Revista Ciência Agronômica, Fortaleza, v. 33, n. 1, p. 29-32, 2002.

LIMA JUNIOR, M. J. V. (Ed.). Manual de procedimentos para análise de sementes florestais. Manaus: UFAM, 2010. $146 \mathrm{p}$.

LORENZI, H.; SOUZA, H. M.; COSTA, J. T. M.; CERQUEIRA, L. S. C.; FERREIRA, E. Palmeiras brasileiras exóticas e cultivadas. Nova Odessa: Instituto Plantarum, 2004. 416 p.

LUZ, P. B.; PIMENTA, R. S.; PIZETTA, P. U. C.; CASTRO, A.; PIVETTA, K. F. L. Germinação de sementes de Dypsis decaryi (Jum.) Beentje \& J. Dransf. (Arecaceae). Ciência e Agrotecnologia, Lavras, v. 32, n. 5, p. 1461-1466, 2008.

MAGUIRE, J. D. Speeds of germination-aid selection and evaluation for seedling emergence and vigor. Crop Science, Madison, v. 2, n. 1, p. 176-177, 1962. 
MEEROW, A. W. Palm seed germination. Florida: Cooperative Extension Service, 1991. 10 p. (Bulletin, 274).

OLIVEIRA, A. B. de S.; MEDEIROS FILHO, S.; BEZERRA, A. M. E.; BRUNO, R. L. A. Emergência de plântulas de Copernicia hospita Martius em função do tamanho da semente, do substrato e ambiente. Revista Brasileira de Sementes, Londrina, v. 31, n. 1, p. 281-287, 2009.

PIVETTA, K. F. L.; SARZI, I.; ESTELLITA, M.; BECKMANN-CAVALCANTE, M. Z. Tamanho do diásporo, substrato e temperatura na germinação de sementes de Archontophoenix cuninghamii. Revista de Biologia e Ciências da Terra, João Pessoa, v. 8, n. 1, p. 126-134, 2008.
REGO, S. S.; NOGUEIRA, A. C.; KUNIYOSHI, Y. S.; SANTOS, A. F. dos. Germinação de sementes de Blepharocalyx salicifolius (H. B. K.) Berg. em diferentes substratos e condições de temperaturas, luz e umidade. Revista Brasileira de Sementes, Londrina, v. 31, n. 2, p. 212-220, 2009.

TORRES, S. B. Influência do tamanho das sementes de Acacia gomifera no desenvolvimento das mudas. Agropecuária Catarinense, Florianópolis, v. 7, n. 2, p. 5, 1994. 
